\title{
FIRST RECORD OF THE FAMILY ANYPHAENIDAE (ARACHNIDA: ARANEAE) FROM THE CHIAPAS AMBER (EARLY MIOCENE, MEXICO)
}

\author{
MIGUEL ÁNGEL GARCÍA-VILLAFUERTE (D) \\ Museo de Paleontología "Eliseo Palacios Aguilera", Departamento de Paleontología, Dirección de Gestión, \\ Investigación y Educación Ambiental, Secretaría de Medio Ambiente e Historia Natural, Calzada de las \\ Personas Ilustres s/n. C.P. 29000. Antiguo Parque Madero, Tuxtla Gutiérrez, Chiapas, Mexico. \\ mgarciavillafuerte@yahoo.com.mx
}

\begin{abstract}
The first record of the spider family Anyphaenidae for the early Miocene Mexican Chiapas amber, a juvenile from Simojovel de Allende, is described. The specimen is assigned to the subfamily Anyphaeninae, based on the position of the tracheal spiracle.
\end{abstract}

Keywords: Chiapas, Araneae, Anyphaeninae, Miocene, amber.

RESUMO - É descrito o primeiro registro da família Anyphaenidae para âmbar de Chiapas, México, uma aranha juvenil, do Mioceno inferior de Simojovel de Allende. O espécime é atribuído à subfamília Anyphaeninae, com base na posição da espiráculo traqueal.

Palavras-chave: Chiapas, Araneae, Anyphaeninae, Mioceno, âmbar.

\section{INTRODUCTION}

Mexican Chiapas amber is considered an important paleontological resource in the world (Solórzano-Kraemer, 2010). This amber was produced by two species of the genus Hymenaea (Leguminosae), H. mexicana (Poinar \& Brown, 2002) and $H$. allendis (Calvillo-Canadell et al., 2010). Recent studies have established its age, ranging from 23.0 to 22.8 Ma (Vega et al., 2009; Serrano-Sánchez et al., 2015), corresponding to the early Miocene (Aquitanian). More than 200 families of arthropods have been recorded from Mexican amber (Solórzano-Kraemer, 2010), including 12 families of spiders (García-Villafuerte, 2019, 2020), but there are no previous records of the family Anyphaenidae.

Anyphaenidae is a relatively homogeneous family of small to medium-sized, wandering hunters, known as "ghost spiders" due to the speed at which they move in a dangerous situation (Brescovit, 1997). Present anyphaenids live in a variety of environments, from forests to deserts (Brescovit, 1997; Ramírez, 2003); they typically live on vegetation, among dead leaves, or under loose bark and rocks (Richman \& Ubick, 2005). They can even be quite abundant in certain crops, such as cotton, sorghum, and rice (Brescovit, 1997; Young \& Edwards, 1990; Taylor \& Pfannenstiel, 2008). At present, Anyphaenidae includes 572 species in 56 genera (World Spider Catalog, 2020). The family has a worldwide distribution but is most diverse in tropical regions (Jocqué \& Diappenaar-Schoeman, 2006), especially in South America, where it counts 29 endemic genera (Ramírez, 2003). From Mexico 49 extant species are currently known (World Spider Catalog 2020), seven of them from Chiapas (GarcíaVillafuerte \& Brescovit, 2019). Fossil Anyphaenidae have been previously recorded from Baltic and Dominican amber (Koch \& Berendt, 1854; Wunderlich, 1988, 2004). This contribution presents the first fossil anyphaenid found in amber from Simojovel de Allende, Chiapas, Mexico.

\section{MATERIAL AND METHODS}

The piece of amber was acquired from a craftsman in Simojovel de Allende, a municipality located approximately $60 \mathrm{~km}$ from Tuxtla Gutiérrez, in the north of Chiapas State (Figure 1), and it is deposited in the Museum of Paleontology "Eliseo Palacios Aguilera", Secretaría de Medio Ambiente e Historia Natural (SEMAHN), located in the city of Tuxtla Gutiérrez, Chiapas. The piece of amber originates from the mine "Los Pocitos" (17 $80^{\prime} 48^{\prime \prime} \mathrm{N}$ and $\left.92^{\circ} 42^{\prime} 30^{\prime} \mathrm{W}\right)$, which correspond to the lower portion of the Mazantic Shale, dated as early Miocene (23 to $22.8 \mathrm{Ma}$, Aquitanian), based on the biostratigraphy of corals, mollusks, microfossils, and strontium isotopes (Vega et al., 2009; Serrano-Sánchez et al., 2015). 
The Mexican Chiapas amber is found mainly in three lithostratigraphic units, known as La Quinta Formation, Mazantic Shale, and Balumtum Sandstone (Figure 2). These units are exposed in the Sierra Madre del Sur in Chiapas, from the north edge of the central depression to Palenque, near the Gulf Coast of Tabasco (Solórzano-Kraemer, 2010). At Los Pocitos, lower Miocene dark gray shales of the Mazantic Shale contain amber fragments, benthic foraminifera, gastropods, bivalves, and crustaceans (Vega et al., 2009).

The specimen is preserved in a cut piece of amber, measuring approximately $1.5 \times 1.1 \times 0.45 \mathrm{~cm}$. The piece was cut and polished prior to being received by the author. Further cutting and polishing was carried out in order to reveal morphological characters. The specimen was assigned to the family Anyphaenidae based on the identification manual of Ubick et al. (2005) and consulting specialized literature on the subfamilies and genera of Anyphaenidae (Ramírez, 1995; Brescovit, 1997).

Anatomical data were gathered using a Zeis Stemi 2000-C stereomicroscope. Photographs were taken with a Canon Eos Rebel SL3 digital camera attached to the stereomicroscope. All measurements were taken with an ocular reticle and are in millimeters. The pattern of description and terminology follows Brescovit (1997).

Abbreviations: ALE, anterior lateral eye; AME, anterior median eye; PME, posterior median eye; PLE, posterior lateral eye. Examined material is deposited in the following institution: IHNFG, Instituto de Historia Natural, Fósil Geografico (acronym historically used for the Paleontological Collection of the Museum of Paleontology "Eliseo Palacios Aguilera" that at present it is housed by the Secretaría de Medio Ambiente e Historia Natural).

\section{SYSTEMATIC PALEONTOLOGY}

\author{
Family ANYPHAENIDAE Bertkau, 1878 \\ Subfamily ANYPHAENINAE Bertkau, 1878
}

Gen. sp. indet.

(Figures 3-4)

Material. Juvenile, IHNFG-5844. Municipality of Simojovel de Allende, Chiapas. Mine "Los Pocitos" (1780'48”N, $92^{\circ} 42^{\prime} 30^{\prime \prime W}$ ). Amber from the Mazantic Shale (Early Miocene, Aquitanian).

\section{DESCRIPTION}

Color in amber: yellow-brown, with very small dark area around eyes, thoracic groove brown. Legs yellow-brown. Opisthosoma yellow with sparse brown motes dorsally. Total length $3.4 \mathrm{~mm}$; carapace $1.4 \mathrm{~mm}$ long, $0.97 \mathrm{~mm}$ wide (Figure $4 \mathrm{~A}$ ). Eye diameters and interdistances (in mm): AME 0.04, ALE 0.05, PME 0.05, PLE 0.05; AME-AME 0.03, AMEALE 0.04, PME-PME 0.1, PME-PLE 0.08, ALE-PLE 0.06 (Figure 4B). Posterior eye row in dorsal view almost straight.

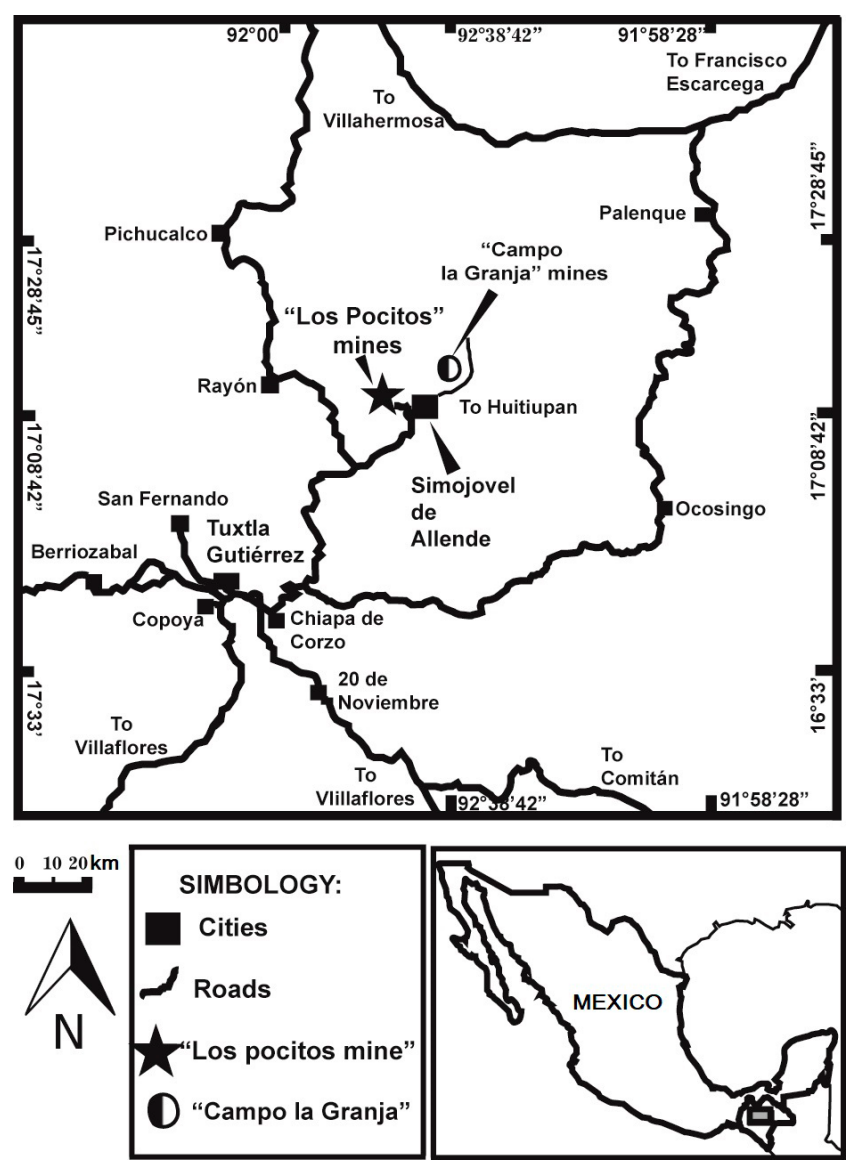

Figure 1. Map showing the location of the "Los Pocitos" mines in the municipality of Simojovel de Allende, Chiapas, Mexico. Modified from García-Villafuerte (2019).

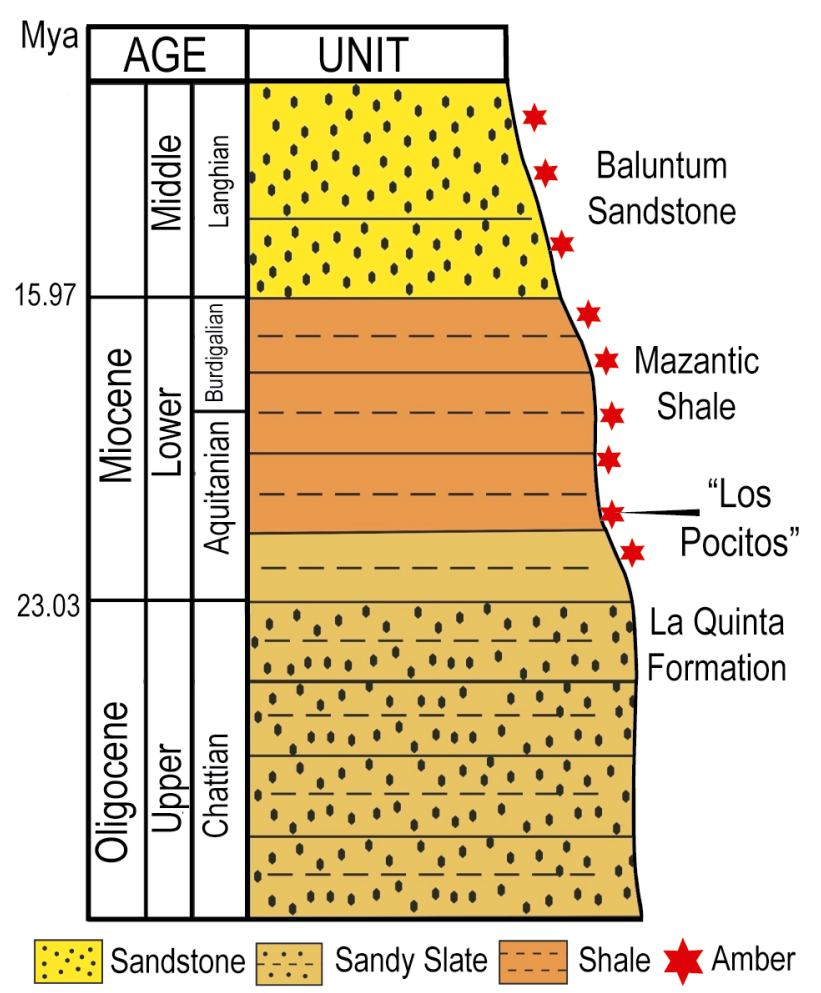

Figure 2. Generalized stratigraphic column of the Simojovel area. Modified from García-Villafuerte (2018). 

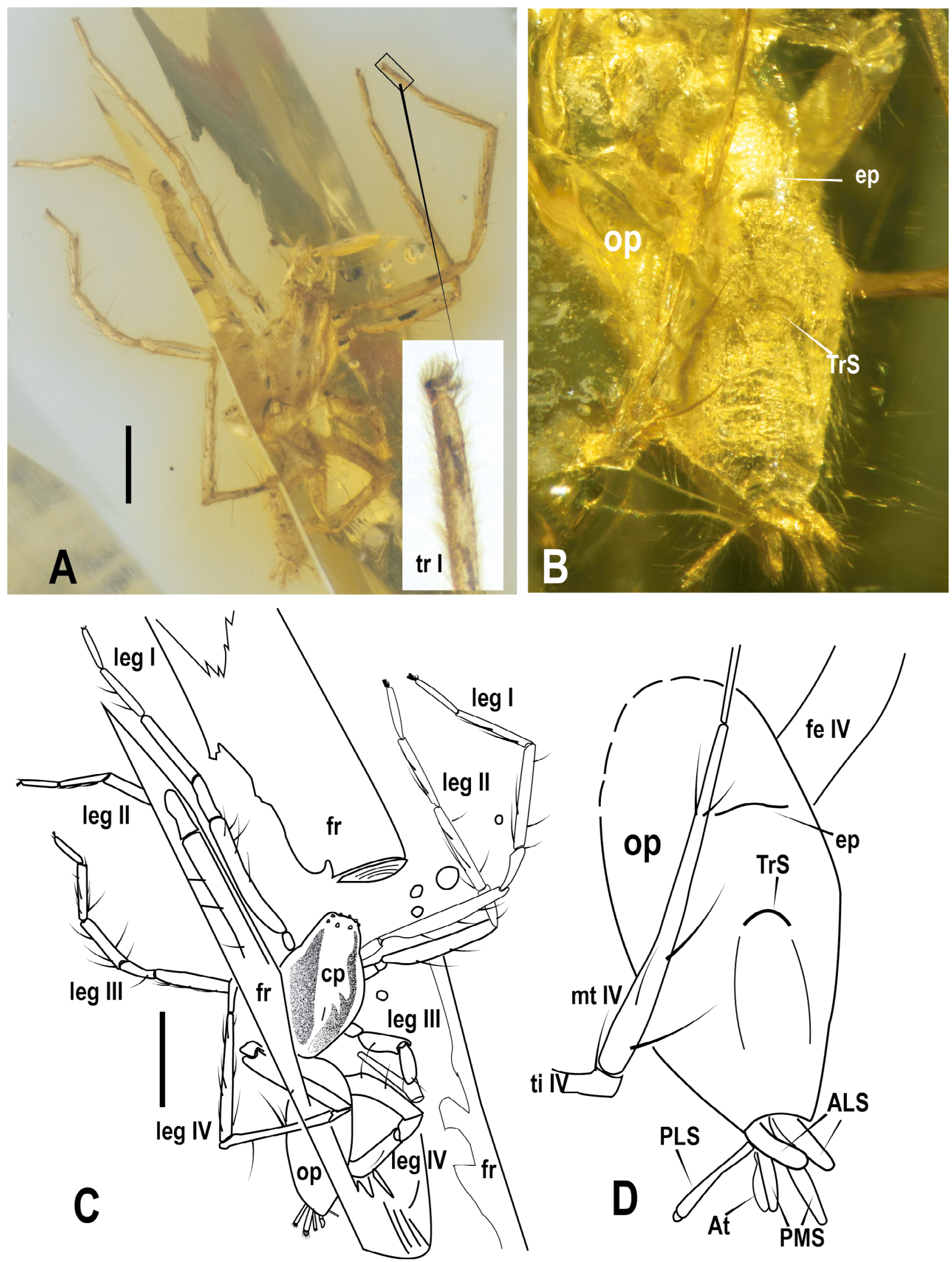

Figure 3. Juvenile anyphaenid, gen. sp. indet., from Mexican Chiapas amber. A, habitus dorsal view, tarsus I is pointed to show the spatulate claw tuft setae. $\mathbf{B}$, opisthosoma, ventral view showing the tracheal spiracle. C, drawing of habitus, dorsal view. D, drawing of opisthosoma, showing the tracheal spiracle and epigastrium. Abbreviations: ALS, anterior lateral spinerets; At, anal tubercle; cp, carapace; ep, epigastrium; fr, fracture; mt, metatarsus; op, opisthosoma; PLS, posterior lateral spinerets; PMS, posterior median spinerets; ti, tibia; TrS, tracheal spiracle; tr, tarsus. Scale bars = $1 \mathrm{~mm}$. 


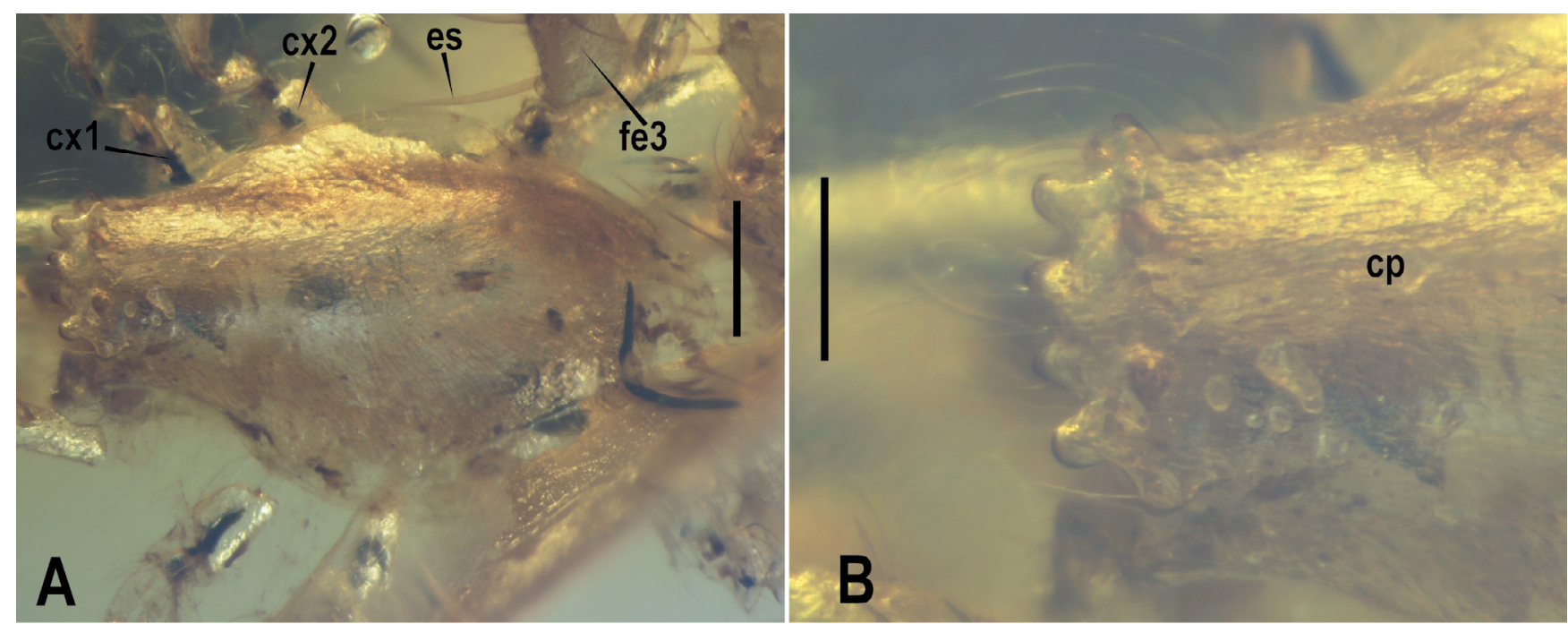

Figure 4. Juvenile anyphaenid, gen. sp. indet., from Mexican Chiapas amber. A, carapace. B, ocular area. Abbreviations: cx1, coxae I; cx2, coxae II; es, spine; fe3, femur III; cp, carapace. Scale bars $=0.3 \mathrm{~mm}$.

Chelicerae and endites not visible. Opisthosoma $1.42 \mathrm{~mm}$ long, $0.65 \mathrm{~mm}$ wide. Femur measurements in mm: I 1.2, II 1.1, III 0.95, IV ?. Leg spination: I femur d1-1-1, p0-0-1; tibia v2-2-2, metatarsus v2-2-0; II femur d1-1-1, tibia v2-22, metatarsus v2-2-0; III femur d1-1-2, p0-0-1; tibia d1-0-1, p0-1-0; metatarsus d2-0-2, v1-0-0, p1-0-1; IV femurd1-1-1, p0-0-1, r0-0-1; tibia d0-1-0, v2-0-2, p1-0-0; metatarsus v22-2, p1-1-1, r1-1-1.

\section{DISCUSSION AND CONCLUSIONS}

\section{Morphological interpretation}

Even though the specimen is a juvenile, there are morphological characteristics that allow a taxonomic identification. The specimen is assigned to Anyphaenidae based on two principal characteristics of the family: their spatulate claw tuft setae (Figure 1A) and the position of the tracheal spiracle (Figures 1B, D), which is situated at one third of the opisthosoma length from the spinnerets or even closer to the epigastrium (Brescovit, 1997; Richman \& Ubick, 2005; Jocqué \& Dippenaar-Schoeman, 2006; Ramírez, 2014).

In a cladistic analysis of the family, Ramírez (1995) divided Anyphaenidae into three subfamilies: Amaurobioidinae, Anyphaeninae, and Malenellinae. Later, Ramírez (2014) indicated that the placement of Malenella (the sole representative of the subfamily Malenellinae) should be reevaluated. In a recent phylogenetic analysis, Anyphaenidae is strongly supported with two subfamilies, Anyphaeninae and Amaurobioidinae, being the genus Malenella (Malenellinae) transferred to the subfamily Macrobuninae in Amaurobiidae (Wheeler et al., 2017).

In a revision of Amaurobioidinae at the genus level, Ramírez (2003) commented that the relationships among the genera of Anyphaeninae are practically unknown. In this study, based on morphological characters, the Anyphaeninae appeared as paraphyletic with respect to Amaurobioidinae. However, recent studies using sequencing data have found support for the monophyly of anyphaenines (Wheeleer et al., 2017; Ceccarelli et al., 2019). The fossil specimen in the present study is placed in the subfamily Anyphaeninae because in anyphaenines the tracheal spiracle is located at the midpoint (Figures 3B, D) or closer to the epigastrium than to the spinnerets (Brescovit, 1997; Ramírez, 2003). In contrast, most species of Amaurobioidinae have the tracheal spiracle closer to the spinnerets than to the epigastrium (Ramírez, 2003).

The subfamily Anyphaeninae was revised at the genus level by Brescovit (1997). Unfortunately, the specimen is a juvenile, lacking genital structures, which are important in the taxonomy of anyphaenines; other key structures, such as the endites, were damaged by fractures in the amber and are not visible. For these reasons, it seems impossible to convincingly assign the specimen to a genus.

\section{Fossil records of Anyphaenidae}

The family was documented for first time in the fossil record by Koch \& Berendt (1854), with the description of 'Anyphaena' fuscata, the oldest anyphaenid found in Baltic amber (44 Ma). However, Wunderlich (2004) claimed that the specimen described by Koch \& Berendt (1854) might not be an Anyphaenidae, because it lacks spatulate claw tuft setae. Nevertheless, he also mentioned that the juvenile female specimen, referred as the hypotype of $A$. fuscata by Petrunkevitch (1946), which shows the advanced tracheal spiracle, a classical Anyphaeninae synapomorphy, might be a member of an undescribed and extinct anyphaenid genus. Magalhaes et al. (2020) mentioned that this specimen might be assignable to Anyphaenidae crown. Wunderlich (1988) described three species from Dominican amber (20-17 Ma), 
which he placed in three extant genera (Anyphaenoides bulla, Lupettiana ligula and Wulfila spinipes). The present paper adds the Miocene of Central America. With four named and one unnamed species, the fossil record of Anyphaenidae is poor in comparison with many other spider families. Possibly this is because anyphaenids are very fast spiders that often had the chance to escape from the resin. Another important reason is that Anyphaenidae is a mainly American group (World Spider Catalog, 2020), and they are expected to be poor in amber from the rest of the world, the extensively studied Baltic amber for example.

\section{ACKNOWLEDGEMENTS}

I am very grateful with $B$. Huber for the revision of the manuscript and his important comments. Many thanks to M. Ramírez for his important comments and to P. Selden for reviewing the manuscript. To G.F. Carbot-Chanona and S. Martínez for the additional remarks. To the Instituto de Ciencia, Tecnología e Innovación de Chiapas, through the support for researchers of the SEI (Sistema Estatal de Investigadores) for the donation of the photographic equipment. Many thanks to Flor de Guadalupe Quero Heredia (Universidad Politécnica de Chiapas) for the help to polish the piece of amber. This research was supported by the Chiapas State Government, through the Instituto de Ciencia, Tecnología e Innovación de Chiapas, in the project "Estudio de la araneofauna (Arachnida:Araneae) fósil y actual de Simojovel de Allende Chiapas" (ID 2019-1048). This paper is included in the project "Prospección y Resguardo del Patrimonio Paleontológico de Chiapas".

\section{REFERENCES}

Bertkau, P. 1878. Versuch einer natürlichen Anordnung der Spinnen, nebst Bemerkungen zu einzelnen Gattungen. Archiv für Naturgeschichte, 44:351-410.

Brescovit, A.D. 1997. Revisão de Anyphaeninae Bertkau a nível de gêneros na região Neotropical (Araneae, Anyphaenidae). Revista Brasileira de Zoologia, 3:1-187. doi:10.1590/S010181751996000500001

Calvillo-Canadell, L.; Cevallos-Ferriz, S.R.S. \& Rico-Arce, L. 2010. Legume flowers preserved in amber from Simojovel de Allende Chiapas, Mexico. Review of Palaeobotany and Palynology, 160:126-134. doi:10.1016/j.revpalbo.2010.02.007

Ceccarelli, F.S.; Koch, N.M.; Soto, E.M.; Barone, M.L.; Arnedo, M.A. \& Ramírez, M.J. 2019. The grass was greener: repeated evolution of specialized morphologies and habitat shifts in ghost spiders following grassland expansion in South America. Systematic Biology, 68:63-77. doi:10.1093/sysbio/ syy 028

García-Villafuerte, M.A. 2018. Primer registro fósil de un lapsino (Araneae, Salticidae) en el ámbar de Chiapas, México. Boletín de la Sociedad Geológica Mexicana, 70:689-708.

García-Villafuerte, M.A. 2019. Metagonia esquincacanoi sp. nov.: el primer registro fósil de la familia Pholcidae (Arachnida: Araneae) para el ámbar de Chiapas, México.
Revista Mexicana de Biodiversidad, 90:e902927. doi:10.22201/ ib.20078706e.2019.90.2927

García-Villafuerte, M.A. 2020. Una "araña pirata” (Araneae: Mimetidae) en el ámbar de Mioceno Temprano y actualización del listado de arañas fósiles para Chiapas, México. Acta Biológica Colombiana, 25:155-161. doi:10.15446/abc. v25n1.74722

García-Villafuerte, M.A. \& Brescovit, A.D. 2019. Nuevo registro de sinantropía de Filistatoides insignis (Araneae: Filistatidae) en México y actualización del listado de arañas actuales de Chiapas. Acta Zoológica Mexicana, 35:1-8. doi:10.21829/ azm.2019.3501136

Jocqué, R. \& Dippenaar-Schoeman, A.S. 2006. Spider families of the World. Tervuren, Musée Royal de l'Afrique Central, 336 p.

Koch, C.L. \& Berendt, G.C. 1854. Die im Bernstein befindlichen Myriapoden, Arachniden und Apteren der Vorwelt. In: G.C. Berendt (ed.) Die in Bernstein befindlichen organischen Reste der Vorwelt gesammelt in Verbindung mit Mehreren bearbeitetet und herausgegeben von Dr. Georg Carl Berendt, Nicolai, $124 \mathrm{p}$.

Labarque, F.M.; Soto, E.M.; Ramírez, M.J. \& Arnedo, M.A. 2015. Chasing ghosts: the phylogeny of Amaurobioidinae ghost spiders (Araneae, Anyphaenidae). Zoologica Scripta, 44:550-561. doi:10.1111/zsc.12119

Magalhaes, I.L.F.; Azevedo, G.H.F.; Michalik, P. \& Ramírez, M.J. 2020. The fossil record of spiders revisited: implications for calibrating trees and evidence for a major faunal turnover since the Mesozoic. Biological Reviews, 95:184-217. doi:10.1111/ brv.12559

Petrunkevitch, A.I. 1946. Fossil spiders in the collection of the American Museum of Natural History. American Museum Novitates, 1328:1-36.

Poinar, G. \& Brown, A. 2002. Hymenaea mexicana sp. nov. (Leguminosae: Caesalpinioideae) from Mexican amber indicates Old World connections. Botanical Journal of the Linnean Society, 139:125-132. doi:10.1046/j.1095-8339.2002.00053.x

Ramírez, M.J. 1995. A phylogenetic analysis of the subfamilies of Anyphaenidae (Arachnida, Araneae). Entomologica Scandinavica, 26:361-384. doi:10.1163/187631295X00053

Ramírez, M.J. 2003. The spider subfamily Amaurobioidinae (Araneae, Anyphaenidae): a phylogenetic revision at the generic level. Bulletin of the American Museum of Natural History, 277:1-262. doi:10.1206/0003-0090(2003)277<0001:TSSAAA $>2.0 . \mathrm{CO} ; 2$

Ramírez, M.J. 2014. The morphology and phylogeny of dionychan spiders (Araneae: Araneomorphae). Bulletin of the American Museum of Natural History, 390:1-374. doi:10.1206/821.1

Richman, D.B. \& Ubick, D. 2005. Anyphaenidae. In: D. Ubick; P. Paquin; P.E. Cushing \& V. Roth (eds.) Spiders of North America: an identification manual, American Arachnological Society, p. 66-67.

Serrano-Sánchez, M.L.; Guerao, G.; Centeno-García, E. \& Vega, F.J. 2016. Crabs (Brachyura: Grapsoidea: Sesarmidae) as inclusions in Lower Miocene amber from Chiapas, Mexico: Boletín de la Sociedad Geológica Mexicana, 68:37-43.

Solórzano-Kraemer, M.M. 2010. Mexican amber. In: D. Penney (ed.) Biodiversity of fossils in amber from the major World deposits, Siri Scientific Press, p. 42-56.

Taylor, R.M. \& Pfannenstiel, R.S. 2008. Nectar feeding by wandering spiders on cotton plants. Environmental Entomology, 37:9961002. doi:10.1093/ee/37.4.996 
Ubick, D.; Paquin, P.; Cushing, P. \& Dupérré, N. 2005. Spiders of North America: an identification manual. Keene, American Arachnological Society, $377 \mathrm{p}$.

Vega, F.J.; Nyborg, T.; Coutiño, M.A.; Solé, J. \& HernándezMonzón, O. 2009. Neogene Crustacea from Southeastern Mexico. Bulletin of the Mizunami Fossil Museum, 35:51-69.

Wheeler, W.C. et al. 2017. The spider tree of life: phylogeny of Araneae based on target-gene analyses from an extensive taxon sampling. Cladistics, 33:576-616. doi:10.1111/cla.12182

World Spider Catalog. 2020. World spider catalog. Natural History Museum Bern. Available at http://wsc.nmbe.ch; accessed on 01/01/2020. doi:10.24436/2
Wunderlich, J. 1988. Die fossilen Spinnen im dominikanischen Bernstein. Beiträge zur Araneologie, 2:1-378.

Wunderlich, J. 2004. Fossil spiders (Araneae) of the family Anyphaenidae in Baltic and Dominic amber. Beiträge zur Araneologie, 3:1686-1688.

Young, O.P. \& Edwards, G.B. 1990. Spiders in United States field crops and their potential effect on crop pests. Journal of Arachnology, 18:1-27.

Received in 14 January, 2020; accepted in 28 April, 2020. 